\title{
HYDATID CYST PRESENTING AS OVARIAN CYST: A CASE REPORT
}

\author{
Helen Kamei ${ }^{1}$, Th. Digel ${ }^{2}$, L. Sushila ${ }^{3}$, Kh. Paikhomba ${ }^{4}$
}

\section{HOW TO CITE THIS ARTICLE:}

Helen Kamei, Th. Digel, L. Sushila, Kh. Paikhomba. "Hydatid Cyst Presenting as Ovarian Cyst: A Case Report". Journal of Evolution of Medical and Dental Sciences 2015; Vol. 4, Issue 49, June 18; Page: 8612-8614, DOI: $10.14260 /$ jemds/2015/1246

ABSTRACT: Echinococcosis is a zoonotic disease which may present as potential health hazard to human. In developing country like India, it is a significant health problem. Surgery is the treatment of choice for hydatid cyst. Recurrence may be avoided by antihelminthic supplements post-surgery.

KEYWORDS: Echinococcosis, Hydatid cyst, Ovarian cyst.

INTRODUCTION: Hydatid cyst, caused by Echinococcus granulosus is a zoonotic disease. In human, it is potentially dangerous depending on size and organ location.(1)

Liver and lungs are usually the common sites, primary peritoneal involvement is Rare.(2)

CASE REPORT: A 48 years old female patient was admitted with complaints of pain lower abdomen for the last 11 years. The pain was aggravated during the last 2 months following physical exertions. She had abdominal hysterectomy 11 years back for adenomyosis. Physical examination did not reveal much except for cystic mass palpated during $\mathrm{p} / \mathrm{v}$ examination. Ultrasound showed findings suggestive of left ovarian cyst, multiloculated and normal sized right ovary.

Exploratory laparotomy revealed the cyst embedded in dense adhesions of gut and omentum. Gradual adhesiolysis revealed the cyst which ruptured exposing 8 milky colored cysts of various sizes. Saline irrigation was done and laparotomy concluded. Post-operative period was uneventful. Histopathology of the specimen read laminated membrane and detached scolices and brood capsules. No ovarian tissue was identified. Cytological smear prepared from the sediments (hydatid sands) of cystic fluid showed many scolices, brood capsules and detached hooklets. (Fig. 2) Eosinophil count preoperative was 3\%. Post-operative AEC read 600/mm3. She was discharged with advice of albendazole $400 \mathrm{mg}$ daily for 28 days.

DISCUSSION: Echinococcosis is a significant health problem in India, considering the fact that it is a zoonotic disease and man is an accidental host. In the duodenum, the embryos hatch, enter the portal vein and are ultimately carried to liver. Some embryos enter pulmonary circulation where the lungs act as second filter. A few entering the general circulation account for its occurrence in unusual sites. Primary peritoneal echinococcosis is very rare.

Diagnosis preoperatively maybe done by clinical findings, imaging and laboratory Tests.(3) Surgical removal carries the best prognosis and is the treatment of Choice. ${ }^{(4)}$ Recurrence post-surgery is $2-25 \%$. So antihelmenthics may be given post-surgery. 


\section{CASE REPORT}

\section{REFERENCES:}

1. Mehra BR., Thawait AP., Gupta DO., Narang RR. Giant abdominal hydatid cyst masquerading as ovarian malignancy. Singapore Med J2007; 48 (11); 284-286.

2. Halder A., Pati S., Khaled, Halder S. An unusual case of hydatid cyst of the ovary and pouch of douglas. J Obstet Gynecol India2010; 60; 345-347.

3. Sailes Ray, Mimi Gangopadhyay. Hydatid cyst of ovary - a rare entity. J Turkish-German Gynecol Assoc2010; 11; 63-4

4. Husnu Gorgen, Murat Api, Ahmet Cetin. Primary adnexial hydatid cyst mimicking ovarian tumour. J Turkish-German Gynecol Assoc2009; 10; 232-4.

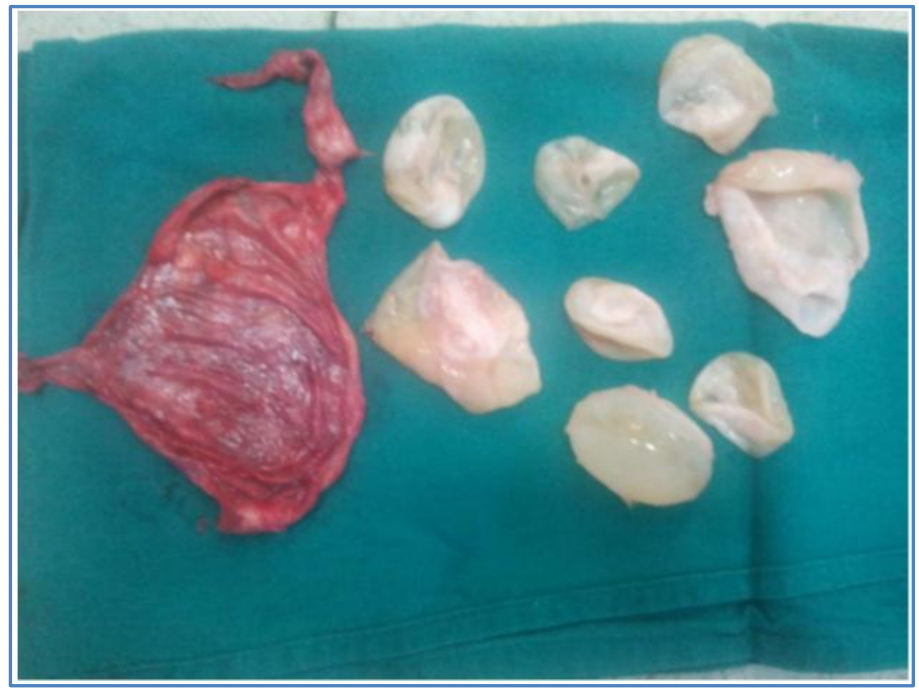

Fig. 1

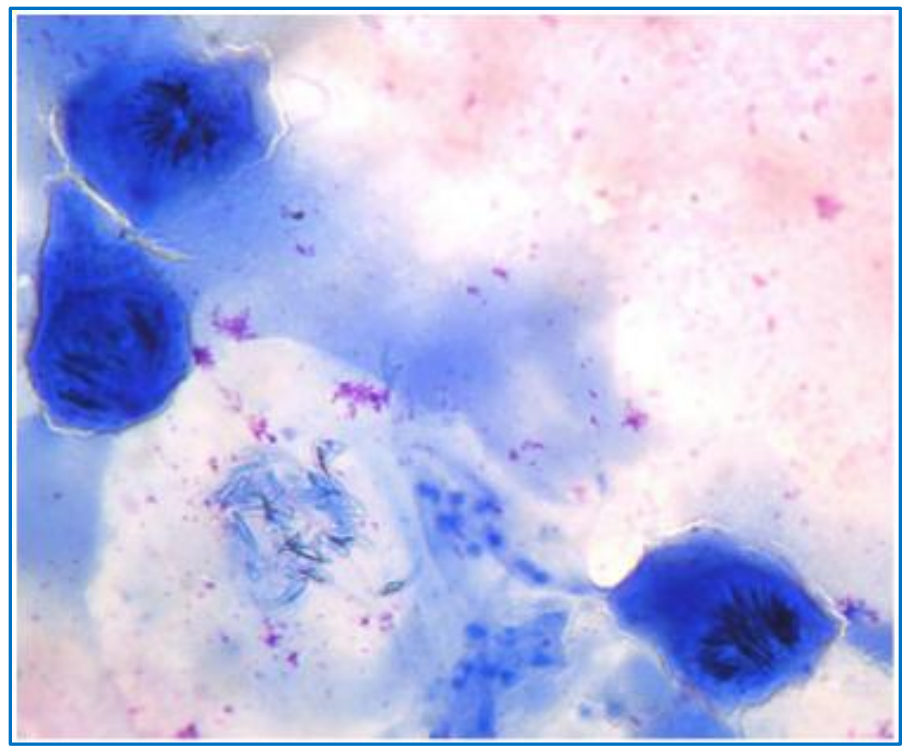

Fig. 2: Leishman x 40 


\section{AUTHORS:}

1. Helen Kamei

2. Th. Digel

3. L. Sushila

4. Kh. Paikhomba

\section{PARTICULARS OF CONTRIBUTORS:}

1. Assistant Professor, Department of Obstetrics \& Gynaecology, JNIMS.

2. Assistant Professor, Department of Obstetrics \& Gynaecology, JNIMS.

3. Assistant Professor, Department of Pathology, JNIMS.

FINANCIAL OR OTHER COMPETING INTERESTS: None
4. Assistant Professor, Department of Obstetrics \& Gynaecology, JNIMS.

\section{NAME ADDRESS EMAIL ID OF THE CORRESPONDING AUTHOR:}

Dr. Helen Kamei, Department of Obstetrics \& Gynaecology, JNIMS, Imphal East,

Manipur-795005.

E-mail: helendrkamei@yahoo.in

Date of Submission: 27/05/2015. Date of Peer Review: 28/05/2015. Date of Acceptance: 11/06/2015. Date of Publishing: 18/06/2015. 